\title{
エベネザー・ハワードの田園都市論とオープンスペースの位置づけ
}

\section{Garden City Theory of Ebenezer Howard and His Vision on Open Space}

村上暁信*

Akinobu MURAKAMI

\begin{abstract}
摘要：エベネザー・ハワード $(1850-1928)$ は, 1898 年に'Tomorrow : A Peaceful Path to Real Reform' を著した。その中で田園都市という新しい都市の建設を提案し，その後の都市計画に多大 な影範を与えた。ハワードは著書の中ではオープンスペースの重要性をうたっているが，実際の建設 に際してはほとんど言及していない。田園都市論の形成過程を検討することにより，彼の関心はむし ろ人間の技術の統合である都市建設という行為により多くの労苦が取り除かれることと，協同の原則 に基ついた社会をつくりあげることにあったということが考察された。
\end{abstract}

\section{1.はじめに}

1898 年にエベネザー・ハワードによって著わされた,

'Tomorrow: A Peaceful Path to Real Reform' (1902 年に 'Garden Cities of To-Morrow'「明日の田園都市」と 改題されて再版）は，これまで現代都市計画運動を指導し，その 目標を定める上で非常に大きな働きをしてきだとされている。 しかしその一方で, この本が真に理解されることは少なかったと もいわれている。

18 世紀にイギリスで起こった産業革命はその後急速に広まり， 社会生活の様々な面で重要な問題を派生させた。特に農村から都 市への人口流入とそれに伴う都市における住環境の劣悪化は深刻 な問題であり, 田園都市論もこれらの問題解決のための方策のひ とつであるとハワードは位置づけている。

ハワードは都市, 農村, そして新たな形態である都市農村（田 園都市）のそれぞれの特徴をダイアグラム（図一1）に示して, 都市と農村のどちらの不利面からも解放された田園都市の建設を 提案した。

田園都市の姿はダイアグラムで示されている（図ー2，3）。 その大きさは約 6,000 エーカーであり, 中央部の 1,000 エーカー が市街地として計画されている。中心から 6 本のブールヴァール が放射状に出て市街地を 6 等分し, 中央には大公園が設置され, さらにその中心には公共建築物が配置されている。市街地の外周 には鉄道が環状に走り, その外側は製造工場, 病院, 学校等の敷 地と農業用地とされ, 人口は市街地 30,000 人, 農業用地 2,000 人の合計 32,000 人とされている。

ハワードは，田園都市においては人々が快適に生活できるよう に，都市部の中心にも公園，庭園，果樹園，森などを設置する4 としている。また田園都市建設に際しては, 建物を計画するより も先に, 十分な大きさの公園や幅の広い道路等のオープンスペー スを第一に確保する必要がある, ${ }^{5 !}$ と述べている。このことから ハワードは田園都市建設に際して, オープンスペースの設置とい うことを非常に重視していたと考えられるが, 著書以外ではオー プンスペースに関する記述は非常に少ない。

本論においては，田園都市論形成の過程等を検討することによ りハワードの考えた田園都市とはどのようなものであったか，そ してそこではオープンスペースはどのように位置づけられていた かを考察することを目的とする。
オープンスペースについては，農業地帯とは常に別個に記述さ れていることから，ハワードがオープンスペースという際には農 業地带は含まれず，都市部に設置されるものに限られていたと考 えられる。

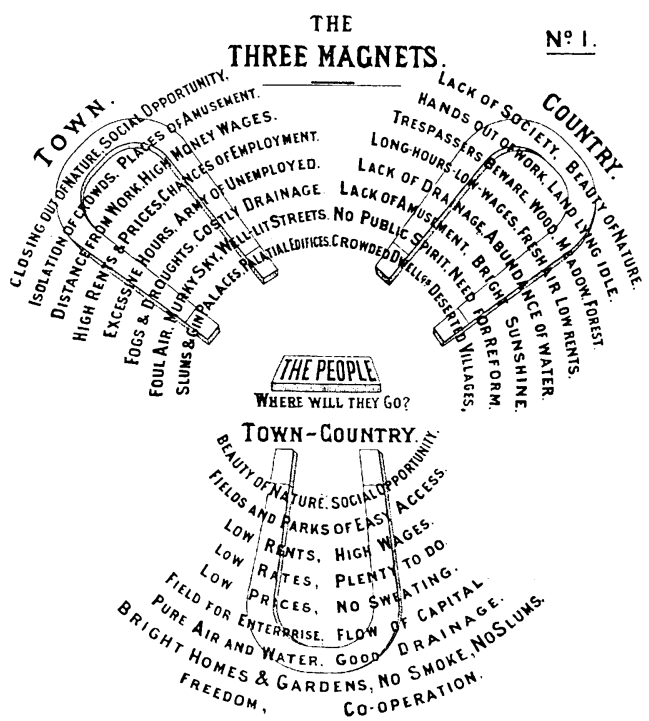

図一１エエベネザー・ハワードのダイアグラム№.1 (出所 : 文献 31))

ハワードは都市部において，公園や庭園，果樹園，森(woods) を設置する゙)としている。またロンドンにあるスラムは将来，公 園, レクリエーション地, アロットメント・ガーデン

(allotment gardens)に変わるであろう, ${ }^{6)}$ としている。従って これらはオープンスペースに含まれると考えられる。

また著書の中で, 公園空間の内 40 エーカーはロード・オーナ メンテーション(road ornamentation)である, "'としている。 同じ著書で, 田園都市においてはブールヴァールやグランドアヴェ ニュー等の道路の設置も提案されている。このことから道路もオー プンスペースに含まれると考えられる。

以上のことから本稿においては, ハワードの言うオープンスペー スとは, 都市部に設置されるものであり，公園，庭園，果樹園，

*東京大学大学院農学生命科学研究科 
森やレクリエーション地, アロットメントガーデン, 道路等であっ たと仮定し，考察を進める。

\section{2. 田園都市論の形成過程}

エベネザー・ハワードは 1850 年にロンドンのフォア街に生ま れた。父親は小さな小売商を営んでおり，生活に経済的問題はな かった。早い時期に親元を離れて学校の寮に入り，15歳のとき には店員として働き始めている。その後 21 歳までは, 職を数回 $-\mathrm{N}: 2-$

\section{(अ)}

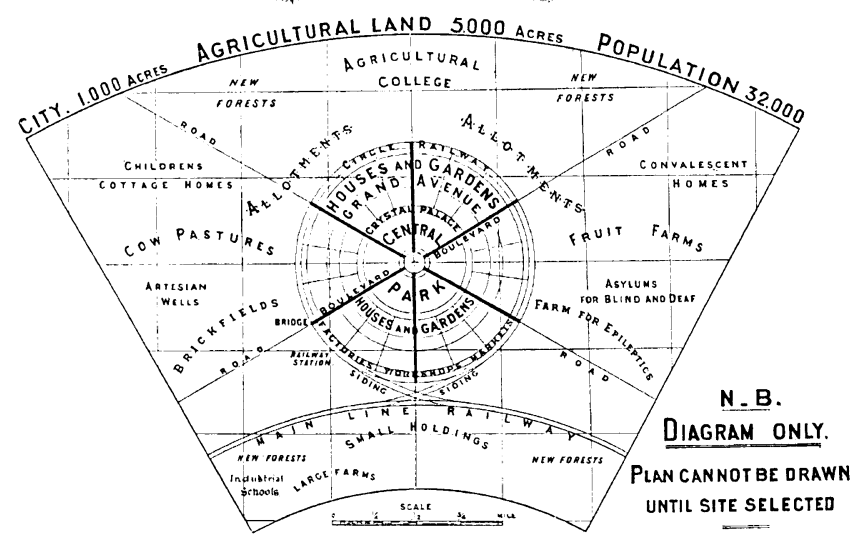

図一２エベネザー・ハワードのダイアグラム№. 2 (出所 : 文献 31))

変えながらロンドンで生活している。

1871 年, 21 歳のときにハワードは友人 2 人とともに, アメリ カで土地を開墾するというある種の野心をもって, ${ }^{8 !}$ アメリカに 渡りネブラスカ州で土地を得て農業を始めたが, これは失敗に終っ ている。このときの失敗について後にハワードは,「協同という ものが欠けていたために，時間と労力の多大な浪費に終わってし まった。」早と述べている。

農業をやめた後，ハワードはシカゴに行き再び事務の職に就い ている。シカゴでの生活については次のように述べている。「シ カゴでの生活は私に多大な影響を与えた。ここで信仰や社会問題 に対する私なりの考え方の大枠が形作られた。」103

1876 年にイギリスにもどったハワードはシカゴで持った社会 問題に対する意識をさらに深めていき，1880 年頃までには新都

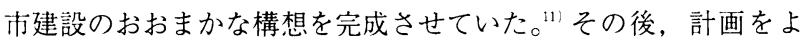
り実際的なものにするために，労働委員会の書記の仕事に就き様々 な経済問題を研究し，いかにして新都市建設を経済的に成功させ るかについて研究している。 ${ }^{121}$

1888 年にハワードはエドワード .ベラミーの「顧みれば」を 読み，そのときの印象を次のように述べている。「その本(「顧み れば」）を読んだ翌朝，私は個人的な利益を無視した，コミュニ ティへの奉仕という考えの上に成り立つ新たな文明社会の誕生の 可能性を実感した。そしてそのような社会の誕生のためにほんの わずかでも自分も協力しょうと決心した。」吕

「顧みれば」の主人公は1887 年のボストンに生活する若者で あり, 彼が催眠術にかけられて眠り続けて 2000 年に目覚め, 社 会の変化に驚くという話である。2000 年のボストンでは，市民 はみな親切であり，差別はなく，市民は個人的な利益をあげるこ とに興味はなく，全員が協力することにより多くの無駄が省かれ た合理的な社会となっている。そのような社会について，ハワー ド自身は「協同の原則(co-operative principles)に基づいた社 会である」 $\rfloor^{147}$ と述べている。ハワードは, 田園都市論形成にとっ
て重要な出来事の一つとしてベラミーの「顧みれば」を読んだこ

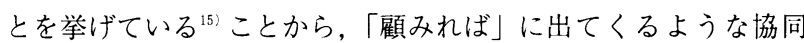
の原則に基づいた社会の誕生のための協力が，田園都市の建設で あったと考えられる。

1898 年にハワードは新都市建設の構想をまとめて 'Tomorrow' として出版した。翌年の1899 年には多くの賛同 者のもとに田園都市協会が設立され，1903 年にはロンドンの中 心から約 35 マイル離れたハートフォードシャーにおいて，3,818

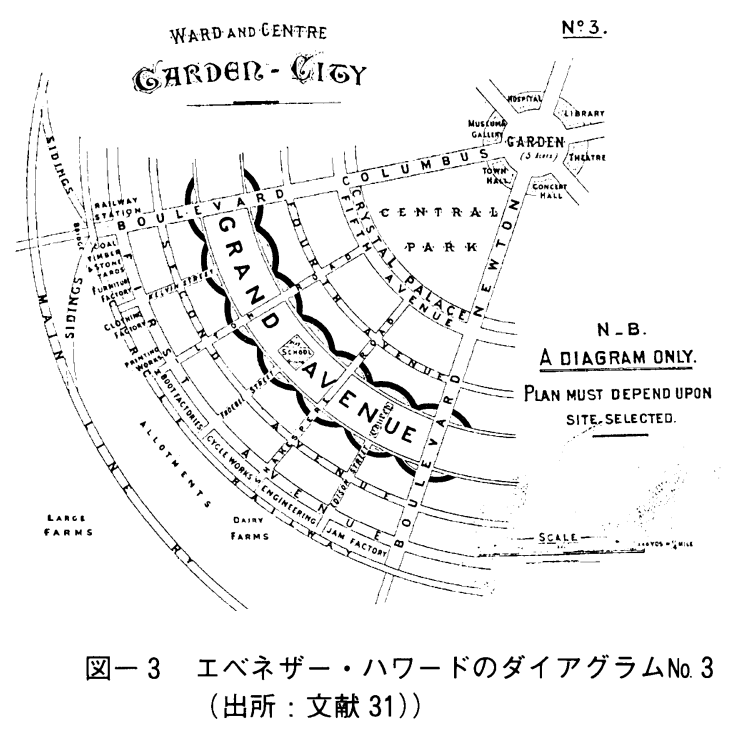

エーカーの土地が購入され, 最初の田園都市レッチワースの建設 が始まった。

\section{3. ハワードの考えた田園都市}

ハワードは1926 年に, 著書('Tomorrow')が書かれ, そして 田園都市協会が設立されたいきさつについて講演しているが，そ の中で自分が都市計画(town planning)的な考え方をし始める きっかけとなったものとして2つのことを挙げている。 ${ }^{16\rangle} 1$ つは, 15 歳のときに知ったスエズ運河とパナマ運河のことを挙げ, 人 間が様々な技術を用いて運河というものを建設することにより長 く険しい航海とそれに伴う労苦が避けられることに強くひかれた と述べている。もう一つは 21 歳のときに, ロンドンのムーアゲー 卜街を歩いたときのことを挙げ，そこの建物の所有者達が協力 (co-operate)してファサードを揃えればもっと街全体が調和し た快適な空間になったはずであり，そういった協同の精神が人々 に久けていることが非常に残念に思われたと述べている。

これら 2 つを都市計画的な考え方をし始めるきっかけとして挙 げていることと, ハワードがベラミーの小説に描かれた協同の原 則に基づく社会を高く評価していることから，

・人間の技術力を用いることによって現状を改善したり労苦を 取り除いていくということ

·人々が協力 (co-operate)していくことで環境を良くしたり, 無駄を省いていくという, 協同の精神に基づいた社会を実現 させること

以上の 2 点がハワードにとっては都市計画の本質的な要素であっ たと考えられる。

ハワードは 'Tomorrow'出版以前に何度か田園都市建設に 関する講演を行っている。その際に毎回聴衆に配付されたものに, 「社会問題の解決を考える際に鍵となる考え方を示した」, ${ }^{17)}$ マス ターキーというダイアグラム (図一 4 ) がある。このダイアグラ ムに付属した説明には，「それ（新都市）は, 思慮深い人々によっ 
て, 社会学や倫理学, 経済学, 衛生学, 物理学, 建築学, 造園学 などの様々な科学を用いて建設されなくてはならない。そしてそ うなれば, 我々の誰しもが持つ, 誠実で利益を度外視した性質に 訴えかけることができるのである。」」8) と書かれている。この説 明から考えて, このダイアグラムでは, 健康, レクリエーション, 教育を重視して, 子供や女性, 老人に配慮した協同的な社会の実 現と, 現存する土地問題や住宅問題, 農業の問題などの社会問題 の解決とを目指していくということがキーをまわす原動力 (THE LEVER)となり, それを受けて思慮深い人々が社会学や倫理学, 経済学, 衛生学, 物理学, 建築学, 造園学などを応用することに より(THE BARREL), 新都市が建設され, 自然や社会を愛す るようになり，また都市と農村の融合も実現し(THE WARDS), また超過密や自由の阻害, 議会的手法による対応の遅れなどがな くなる(PARTS CUT AWAY), ということが表されていると いえる。

すなわち，協同的な社会の実現と現存する社会問題の解決を目 的として様々な技術を総合することにより, 都市と農村の融合で ある田園都市が建設され, その結果様々な無駄が除かれる, とい うことであり，これらはハワードにとっての都市計画の本質的な 要素であると考えられる前記の 2 点と同義であるといえる。この ことから，田園都市論においても，人間の技術力を用いることに よって現状を改善したり労苦を取り除いていくこと, 人々が協力

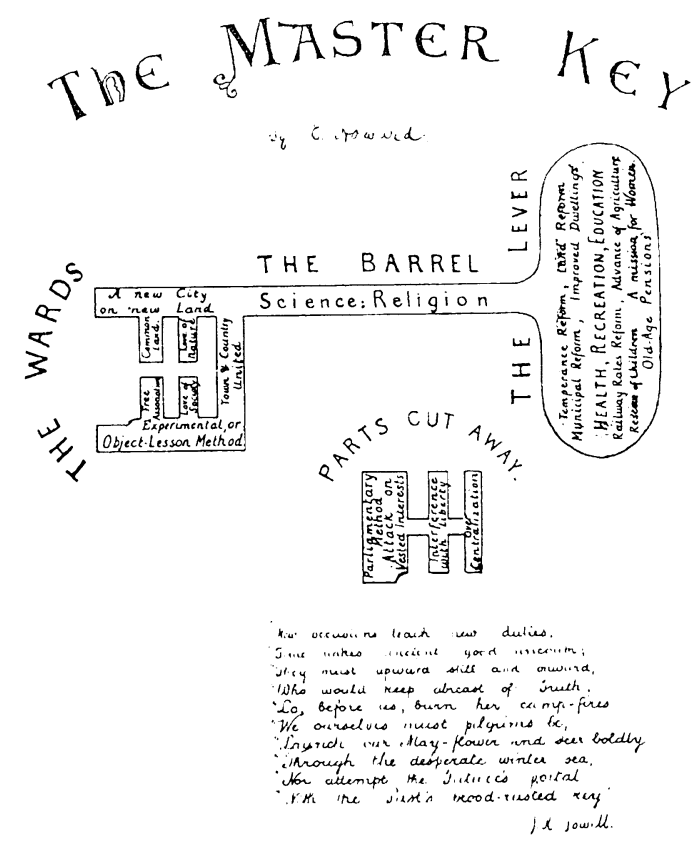

図ー4 エベネザー・ハワードのダイアグラム マスターキー(出所 : 文献 32) )

(co-operate)していくことで環境を良くしたり，無駄を省いて いくという協同の精神に基づいた社会を実現させること，の 2 点 が考え方の基本にあったと考えられる。

実際に, 田園都市には多くの慈善施設が設置され, 多くの公共 心豊かな人々によって運営されるとしており，ハンディキャップ をもった人々もコミュニティに受け入れられる(19)とされている。 またレッチワースにおいて田園都市の理想がどこまで実現された かということについての論文において, レッチワースはその財政 面で理論通りにいかなかったとした上で, それ以上に残念であっ たのは, 協同的家事の形態が創出されなかったことと, 利益を無 視して住民のことを第一に考えた良心的な企業や商店があまり誕
生しなかったことの 2 点である, ${ }^{20)}$ としている。田園都市建設後 にハワードは, 協同住宅(co-operative house)とも呼ばれ，主 に独身者や一人暮しの老人向けの住宅でキッチンが共用となって いる家であるホームスガース(Homesgarth)や，一つの商品を 大量に仕入れて安価で市民に提供する店で, 協同の原則に基づい たものとしてべラミーの小説のなかにも登場する巨大ストア

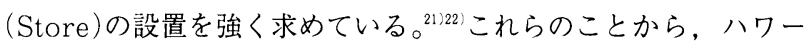
ドは田園都市建設においては協同的な社会の建設を主要な目的と して位置づけていたと考えられる。

また'The Transit Problem and the Working Man' と いう論文 ${ }^{23)} に$ にいて，ハワードは田園都市建設の利点の中でも， 高家賃や高物価, 污れた空気, 煙害, などが取り除かれることと, 職場と住居の近接, 農産物の産地と消費地の近接により長距離通 勤や余分な物資の輸送などの無駄がなくなることを特に強調して いる。このことから，田園都市建設という行為により，様々な無 駄や労苦が取り除かれるということを重要視していたといえる。

\section{4. 田園都市論におけるオープンスペース}

田園都市論の中では, 十分な広さの公園, レクリエーションの 場, 庭園, アロットメントガーデンや果樹園の設置により健康的 で快適な環境がもたらされる，24)とされており，またハワードは 計画の最初の段階で十分な規模の公園や道路等のオープンスペー スが確保される必要がある, ${ }^{25)}$ と述べていることから田園都市に おいてはオープンスペースの確保ということを重視していたと考 えられる。

しかしあるインタビューにおいて，敷地が決まったときに理論 がいかにして実際の計画に応用されるのかという問に対し, ハワー ドは地形に合わせて建物が調和をもって配置されるべき, ${ }^{26)}$ と建 物についてのみ答えて，オープンスペースに関しては全く述べて いない。実際の田園都市建設に際しての提案や建設後の評価にお いて，協同的な社会の実現という点においてはホームスガース (Homesgarth)や巨大ストア(Store)のような具体的なものの設 置に関して言及しているのに対し，オープンスペースに関しては ほとんど言及していない。

また大規模公園に関してはいくらかの説明があるものの，その 他のオープンスペースに関しては詳細な中身の説明はみられない。

また一方でハワードは，田園都市よりも先に建設されたボーン ヴイル（1879 年建設開始）やポートサンライト（1887 年建設開 始）について，庭園やレクリエーションの場が多く，そのため人々 が土に触れる機会が多くなり，健康的ですばらしい環境となって いる，と賞賛したうえで，そのような流れの中から田園都市は生 まれた27) と述べている。

1854 年にロバート・パンバートンによって発表された, 'The Happy Colony' の中では, 農地帯によって周囲を囲まれたコ ロニーの建設が提案されており，その計画図は八ワードのダイア グラムと大変よく似たものとなっている。そこでは広い公園や幅 の広い道路が設置され，いたるところに木や花，特に果樹や桑の 木などが植えられ，健康的で美しい景観をつくる28) とされている。

他にも，1876 年にB.W.リチャードソンによって著わされた 'Hygeia：A City of Health'においても, 美しく健康的な環 境を創り出すためには，公園や庭園などのオープンスペースを十 分に確保する必要がある, ${ }^{29)}$ とされている。これらの論文の影響 をハワードが直接受けたかどうかは定かではないが, 当時の新都 市建設の考え方として健康的な環境をつくるためには広大なオー プンスペースの確保が必要であるという考え方もみられていたと いうことがいえる。

ハワードはオープンスペースに関して, その重要性からいくつ かの形態 (公園, 庭園, レクリエーション地, アロットメントガー 
デン, 森, 果樹園等) のオープンスペースの設置を提案し, また 計画の最初の段階でオープンスペースを確保することも提案して いる。しかし, 果樹園やアロットメントガーデン, 森等の個々の オープンスペースに関して詳細な解説をしていないことや, 著書 以外ではオープンスペースに関してほとんど言及していないこと， ハワードは自分の計画は彼独自のものではなくそれまでにあった 類似の計画を統合したものであるとして, 特に J.S.バッキンガ ムのモデル都市等を参照した ${ }^{30}$ としていること, 田園都市論以前 にも健康的な環境をつくるためには広大なオープンスペースの確 保が必要であるという考え方をしたものもあること等から，オー プンスペースに関するハワードの考え方は，当時の一般的な考え 方に影響を受けたものであり，ハワード自身が考え出したもので はなかったと考えられる。

また著書以外では，オープンスペースに関することよりも，協 同的な社会に関する記述や, 様々な科学や技術を統合して田園都 市を建設することにより多くの労苦や無駄を除くことができると いう内容の記述の方が多いことから，ハワードはオープンスペー スよりもむしろこれら 2 点に強い関心を抱いていたと考えられる。

\section{5.まとめ}

本研究から得られた知見を以下にまとめる。
1）ハワードにとっての田園都市，あるいは田園都市建設とは

a)良心的な人々が様々な科学や技術を統合して新都市を建設す ることにより多くの人が労苦や様々な無駄から解放される

b)新都市においては協同の原則に基づいた社会生活が営まれる という 2 点が主な中身であった。

2 ) 田園都市におけるオープンスペースに関しては オープンスペースの重要性は認識しており, いくつかの形態のオー プンスペースの設置を提案し，また計画の始めの段階でオープン スペースを確保することを提案しているが，このようなオープン スペースに関する考え方は，ハワード以前の考え方の影響を受け たものであったと考えられ，ハワードの関心はむしろ上記の 2 点 にあった。

謝辞: 本研究を進めるにあたって, 東京大学農学部緑地学研究室 の井手久登教授, 武内和彦助教授に御教示を賜りました。また, 株式会社長谷工総合研究所の特別な御配慮により貴重な資料を閲 覧させて頂きました。さらに，イギリス・ハートフォードシャー． カウンティ・レコード・オフィスでも貴重な資料を閲覧させて頂 くとともに御教示を賜りました。この場を借りて御礼申し上げま す。

\section{参考文献}

1) ルイス・マンフォード (1946)：田園 都市理念と現代の計画：明日の田園都 市（エベネザー・ハワード）：鹿島出 版会 : 45

2 ) Ibid.

3 ) Howard, Ebenezer (1913): How Far Have the Original Garden City Ideals Been Realised ?: The Garden City (C.B.Purdom) : London Press : 289

4 ) Howard, Ebenezer (1902): Garden Cities of To-Morrow : Swan Sonnenschein : 130

5 ) Howard, Ebenezer: (Writings of Ebenezer Howard): Hertfordshire County Archive : E/Ho: Folio 3

6 ) Howard, Ebenezer (1902): Garden Cities of To-Morrow : Swan Sonnenschein : 135

7 ) Ibid. : 62

8 ) Howard, Ebenezer (1926): (Paper on progress of his thought on planning, delivered at celebration of the birthday of Letchworth Garden City) : Hertfordshire County Archive : E/Ho : Folio 18
9 ) Macfadyen, Dugald (1933) : Sir Ebenezer Howard and The Town Planning Movement : Manchesster University Press : 9

10) Howard, Ebenezer : Hertfordshire County Archive : $\mathrm{E} / \mathrm{Ho}:$ Folio 18

11) Ibid.

12) Ibid.

13) Ibid

14) Ibid

15) Ibid

16) Ibid

17) Beevers, Robert (1985): Garden City Utopia: Macmillan Press : 37

18) Ibid. : $39-41$

19) Howard, Ebenezer (1902): Garden Cities of To-Morrow : Swan

Sonnenschein : 27

20) Howard, Ebenezer (1913) : How Far Have the Original Garden City Ideals Been Realised ?: The Garden City (C.B.Purdom) : London Press : 292

21) Ibid. : $292-293$

22) Beevers, Robert (1985): Garden City Utopia : Macmillan Press : 110111
23) Howard, Ebenezer (1910) : The Transit Problem and the Working Man: The Planning Review Vol.III : $127-129$

24) Howard, Ebenezer (1902): Garden Cities of To-Morrow : Swan Sonnenschein : 130

25) Howard, Ebenezer : Hertfordshire County Archive : E/Ho : Folio 3

26) Beevers, Robert (1985): Garden City Utopia : Macmillan Press : 97

27) Howard, Ebenezer: Hertfordshire County Archive : E/Ho: Folio 3

28) Pemberton, Robert (1854): The Happy Colony : London Saunders and Otley : $82-83$

29) Richardson, Benjamin Ward (1876): Hygeia A City of Health: Macmillan and Co. : 19-20

30) Howard, Ebenezer (1902) : Garden Cities of To-Morrow : Swan Sonnenschein : 102

31) Howard, Ebenezer (1902): Garden Cities of To-Morrow : Swan Sonnenschein

32) Beevers, Robert (1985) : Garden City Utopia : Macmillan Press : 41

Summary : Ebenezer Howard (1850-1928), who wrote' Tomorrow : A Peaceful Path to Real Reform' in 1898, played an important role in development of town planning. He said that sufficient open spaces must be reserved at once the land was purchased. But in actually, he seemes not to have reserved them. Viewing from progress of Howard's thoughts on planning, characteristic of the garden city theory which Howard himself conceived are summarized as follows. First, what he really wanted to realise was co-operative society. Second, he wanted to get rid of social evils, which many working men suffered from, by constructing a new city-garden city which was built by thoughtful persons in accord with a whole range of sciences. 